\title{
UK scientists fear further cuts
}

\section{Funding jitters rife ahead of government spending review.}

\section{BY DANIEL CRESSEY}

$\mathrm{W}$ ith anxiety rising about what the immediate future may hold for Britain's science funding, the man responsible for the nation's finances is trying to allay researchers' fears.

Science "is a personal priority for me", chancellor of the exchequer George Osborne told reporters on 6 June after a ceremony to mark the completion of the roof of the new $£ 650$-million (US\$1.1-billion) Francis Crick Institute under construction in London.

On 26 June, Osborne is set to unveil the next comprehensive spending review (CSR), which sets spending for government departments. $\mathrm{He}$ said that he hoped to make clear the government's "long-term commitment" to research in the new review, but scientists fear another budget freeze. Asked if he could cut science after his supportive statements, the chancellor said that he would not pre-empt the CSR but added: "You can read between the lines that I'm going to do everything I can to make sure Britain has a bright scientific future."

The previous spending review, in 2010, set budgets for government departments for the four financial years to 2014-15. June's CSR will apply to just the 2015-16 fiscal year - because a new budget will be crafted after a general election in May 2015 - and Osborne has made it clear he wants cuts to most departments.

Despite its short duration, this CSR is important, says Kieron Flanagan, a science-policy researcher at Manchester Business School. "You can do damage in one year" if spending is cut back severely, and whoever wins the election in 2015 would be likely to work from the existing framework, he says.

Analysts are especially keen to know what the government will do with the 'ring fence' that was placed around the science budget in 2010 , freezing it at $£ 4.6$ billion a year. The fence spared core spending areas - such as grants that are awarded by the country's research councils - from the cuts inflicted on other public sectors, although the science budget still lost money in real terms each year. The umbrella group Universities UK has calculated that, when inflation is taken into account, the deficit is $£ 600$ million over the current four-year CSR period.

And, in any event, the ring fence had holes. The 2010 CSR moved capital spending in science - monies allotted to large infrastructure projects such as buildings and facilities - outside the ring fence, away from the core science budget. That made infrastructure vulnerable to cuts, and projects such as the United Kingdom Infrared Telescope in Hawaii face closure as a result (see Nature 486, 168; 2012).

Many policy analysts expect the ring fence around science funding to be retained in the new CSR. But some worry that it may

"The absolutely
crucial thing
is we fund
basic scientific
research -
including in
medicine."
be removed or that additional categories of science money could be moved outside it.

One rumour in circulation is that the Medical Research Council (MRC), which is a major funder of UK medical research, will be moved from the Department for Business, Innovation and Skills - the department in charge of the science budget to the Department of Health, where it might be more vulnerable to cuts or to a change in research focus. In a 6 June statement, Ted Bianco, acting director of the biomedicalfunding charity the Wellcome Trust, called the prospect "ill-advised and potentially damaging", adding that it would shift the balance "from fundamental to applied research when both are essential to medical progress".

Osborne would not comment during the Crick Institute event on a move for the MRC, but said that "the absolutely crucial thing is we fund basic scientific research — including basic scientific research in medicine - and I'm not prepared to do anything that puts that at risk".

James Wilsdon, a science-policy researcher at the University of Sussex, says that another year of flat cash for science would be "painful but survivable". Deeper cuts, he says, would be another matter.

\section{CORRECTION}

The News Feature 'The gun fighter' (Nature 496, 412-415; 2013) wrongly implied that blogger David Codrea had 'outed' gun researcher Garen Wintemute. Wintemute had in fact publicized his own work before Codrea's 2007 blog post. 